Designing blended learning environments organized within the basis of web-assisted modeling in science teaching

Murat Cetinkaya ${ }^{a}$,

Suggested Citation:

New Trends and Issues Proceedings on Humanities and Social Sciences.

Abstract

Murat Cetinkaya, 
New Trends and Issues Proceedings on Humanities and Social Sciences.

1. Introduction

2. Method

3. Design of Blended Learning Environments 


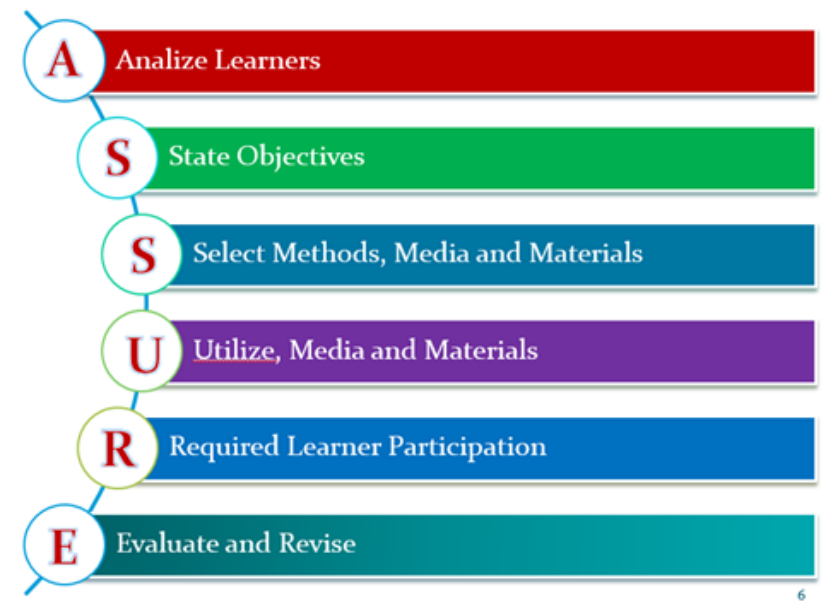

Figure 1. Assure instructional design model

- Analyze Learners

a)

b)

c)

- State objectives

Table 1. Number of Objectives and Subjects/Concepts of Matter and Heat Unit 
- Select Methods, Media and Materials

- Utilize Media and Materials

- Required learner participation

- Evaluate and Revise

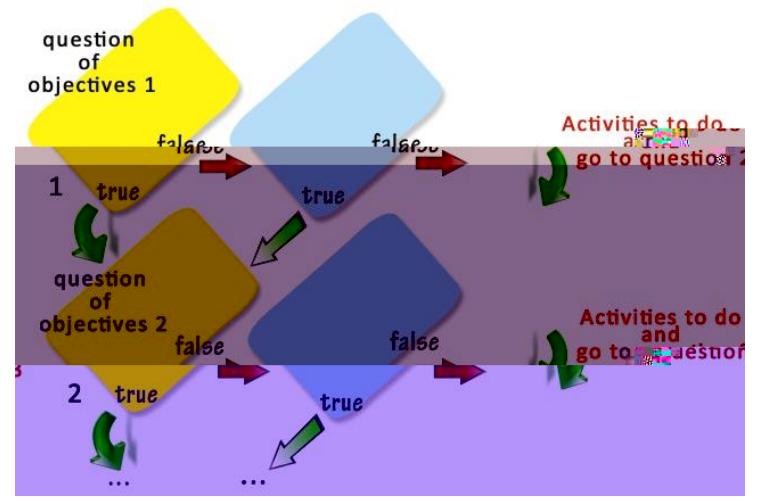

Figure 2. Questions and activities plan prepared for measurement and assessment material 


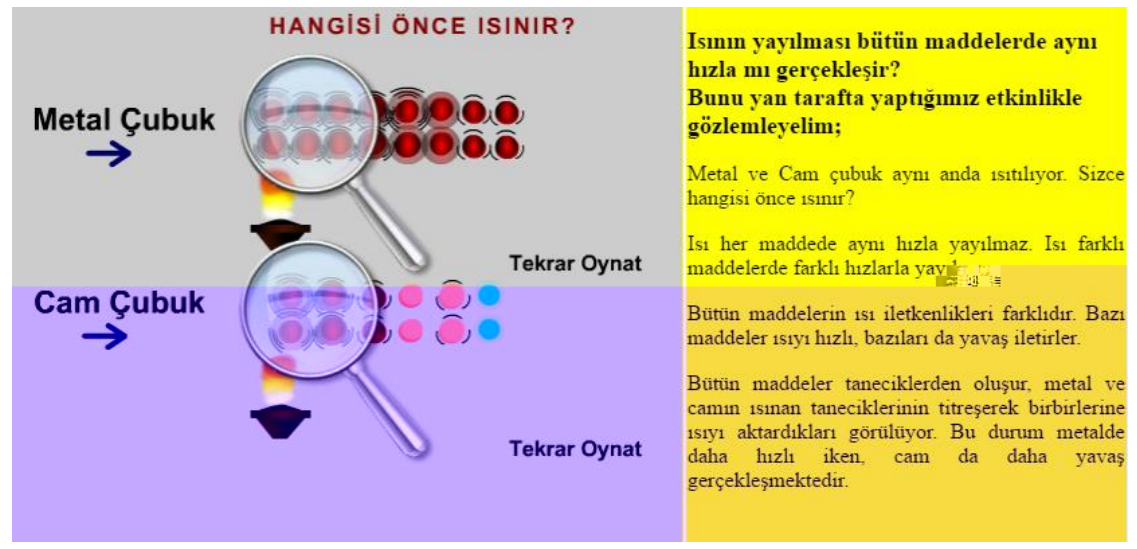

Figure 3. A sample activity

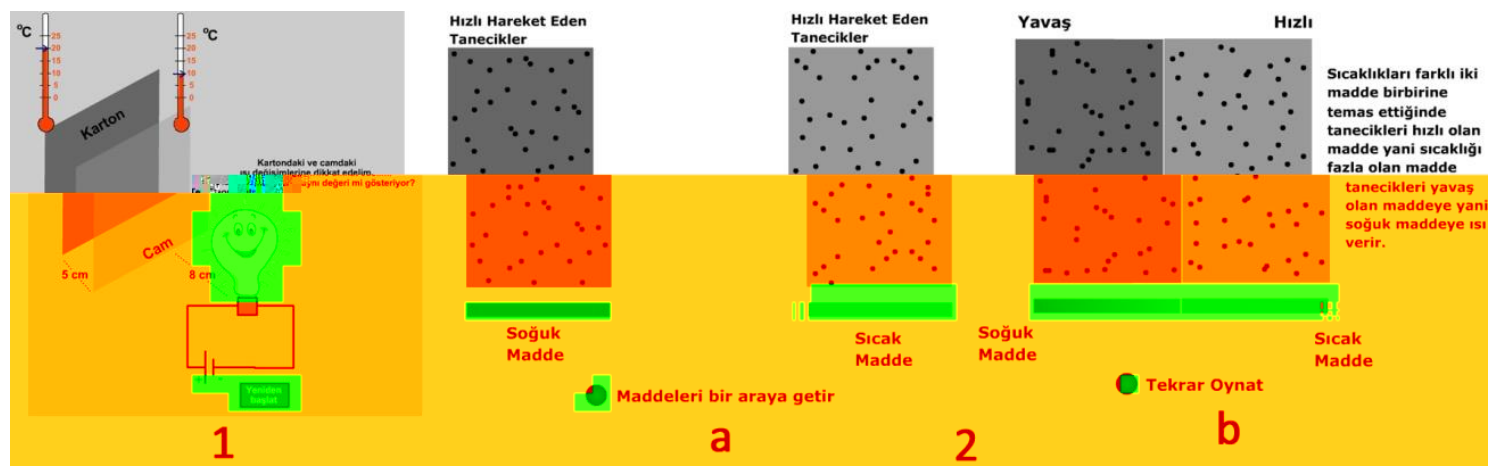

Figure 4. Sample activities for based on modelling

\section{Conclusion and Recommendations}


New Trends and Issues Proceedings on Humanities and Social Sciences.

\section{References}

Usak Universitesi Sosyal Bilimler Dergisi, 9

Internet temelli ogretim tasarımı ve teknolojide yeni yonelimler, Journal of Turkish Studies, 10

Dergisi, 5

Necatibey Egitim Fakultesi Elektronik Fen ve Matematik Egitimi

Interactive Learning Environments, 19

Alan Egitimi Arastırmaları Dergisi, 2

of Research in Science Teaching, 44

Journal

21

T.H.E. Journal,

Ahi Evran Universitesi Kırsehir Egitim Fakultesi Dergisi, 15

Blended learning: How to integrate online \& traditional learning

Academic Social Science Studies, 6

The Journal of

Turk Egitim Bilimleri Dergisi, 10 